\title{
Causality effect of capital market indicators on foreign investment model in Nigeria and South Africa (1980-2013)
}

\author{
${ }^{1}$ Onuorah Anastasia Chi-Chi, Ebiringa, ${ }^{2}$ Oforegbunam Thaddeus, ${ }^{2}$ Okoli \\ Margaret Nnenna \\ ${ }^{I}$ Department of Accounting, Banking and Finance, Delta State University, Delta \\ State, Nigeria \\ ${ }^{2}$ Department of Management Technology, Federal University of Technology, \\ Imo State, Nigeria
}

\begin{abstract}
This study examined causal effects of economic indicators attracting foreign investment inflows in Nigeria and South Africa. The purpose of the study is to investigate the behavioural pattern of economic indicators and determinants of economic indicators of capital market model influencing foreign investment inflows these two countries. The data were sourced from various economic and statistical bulletins of each country. Diagnostic test and Granger causality tests were the main econometric techniques for the analysis. The findings confirmed that for both countries; total value of transaction (TVT) and market capitalisation (MCAP) are the main economic indicators of capital market model (CMD) attracting foreign investment (FI). The study concluded that the identified economic indicators of CMD influenced FI in a short-run equilibrium relationship except interest rate having long-run equilibrium with foreign investment in South Africa. It is recommended that substantial approach and workable policy formulation and implementation in the stock exchange market to improve quality portfolio is highly needed to attract foreign investors in the global financial market.
\end{abstract}

Key words: Foreign investment, Capital market, Granger causality, Industrialisation and Investment, Market capitalization

\section{INTRODUCTION}

Foreign investment is explained by many studies as a trend toward globalization whereby large, multinational firms often have investments in a great variety of countries. Many people see foreign investment in the country as a positive sign and a source for future economic growth. African countries encourage foreign investment through foreign trade. Barron's Business Dictionary (2013) stated that foreign investment is investment by foreigners, citizens and government of one country in industries of another. Foreign investment happens when a company or individual from one nation invests assets or ownership stakes of his/her company into another nation's economy. As globalization is getting intense, it's become very common for big companies to branch out and invest money in companies located in other countries. Companies, maybe, are opening new branches getting attracted by cheaper labour, production and fewer taxes in another country. They may make investment outside their country because the firm being purchased has specific technology, products or access to additional customers that the purchasing firm wants. Overall, foreign investment in a country is a good sign that often leads to growth of job positions and income. As more foreign investment comes into a country, it can lead to even greater investments because this signals the country is economically stable. Thus, foreign investment is summarized as a flow of capital from one nation to another in exchange for significant ownership stakes in domestic companies or other foreign companies. Typically, foreign investor takes somewhat active role in management of the company. In this study, causal effects of economic indicators are investigated to identify the influence of factors attracting foreign investment inflows in Nigeria and South Africa. Thereby, the objective of this study is to investigate the behavioural pattern of economic indicators and determine the influencing economic indicators of foreign investment inflows in both countries.

\section{EMPIRICAL EVIDENCE}

A number of empirical studies have been examined in order to ascertain the impact of macroeconomic variables on foreign investments (FI). Anupan and Krishna (2002) studied the experiences of 29 countries in Sub-Saharan Africa countries (Botswana, Mauritius, Mozambique, Swaziland and Uganda etc.) to ascertain which country has succeeded in attracting fairly large amounts of foreign investment and have generated the interest of international investors by improving their business environment and 
become internationally competitive. This study was based on available data of World Bank on GDP, exchange rate, interest rate and inflation rate from 1980 to 2000 and this way author measured their effect on net inflows of FDI. The study reviewed that Mozambique and Uganda have experienced considerable success in attracting foreign investment in recent periods mainly because fairly successful economic reforms they have implemented. The result revealed that these macroeconomic variables are positively related to FDI. The studies also finds out that the investors and stock market analyst like to operate in the countries where the government have liberal policies for the employment of experience staff on a competition basis. Mohamed (2009) examined the short-run and long-run causal relationship between foreign portfolio investments in Uganda (FDI) based on selected macroeconomic variables namely inflation, money supply and nominal effective exchange rate for post crisis period from 1987 to 1995 and 1999 to 2007 (monthly data). The findings show that there is co-integration between (FPI) stock prices and macroeconomic variables. The results suggest that inflation, money supply and exchange rate seem to significantly affect FPI. These variables were emphasized as the policy instruments by the government in order to stabilize stock prices. Similarly, Maysami (2004) studied the relationship between macroeconomic variables and Singapore stock market index (STI), as well as various Singapore Exchange sector indices - the finance index, the property index, and the hotel index. The study concludes that Singapore's stock market and the property index form co-integration relationship with changes in the short and long run interest rates, industrial production, price levels, exchange rate and money supply.

Salako and Adebusuyi (2000) empirically examined the determinants of foreign direct investment (FDI) in Nigeria. The results indicate that exchange rate, government capital investment in infrastructure and credit to the domestic economy are some of the main factors that influence FDI flow in Nigeria; it also shows that the ratio of external debt to GDO (Debt/GDP) was an important determinant of foreign investment flow. FDI was also observed to be sensitive to domestic interest rate and real per capita income. The study also highlights the need to maintain political stability in order to attract more FDI. Onuorah and Akujuobi (2013) examined the impact of macroeconomic indicators on the performance of foreign portfolio investments in Nigeria between the periods of 1980-2010.

\subsection{Economic Indicators of Capital Market Model Development Review}

Capital market development is the market where medium and long term securities are raised. Kolapo and Adaramola (2012) investigated Nigeria capital market on economic growth within the period of 1970 and 2010. The performance of stock market was examined by considering market capitalisation (MCAP), total new issue (TNI), value of transaction (VLT) and total listed equities and government stock (LEGS) as variables to measure economic growth in Nigeria. Kolapo and Adaramola (2012) based their studied model on the model of Demirque-Kunt and Levine (1996), Levine and Zervos (1996) and Eweh, et al (2009) which examined the linkage between stock market and economic growth. The empirical finding of Kolapo and Adaramola (2012) suggested that the identified variables were stationary and co-integrated and therefore, concluded that market capitalisation and list of equities and government stocks have positive impact on the growth of the economy. However, in the case of our present study, capital operation model will be developed including the following variables (market capitalisation (MCAP), total listing of stock and equity (TLNSE) and total value of transaction (TVT).

\section{Model: Capital Market Development Model}

$$
\begin{aligned}
& F I=f(C M D) \\
& F I=f(M C A P, T L N S E, T V T)
\end{aligned}
$$

Where: $\mathrm{FI}=$ foreign investment;

$\mathrm{CMD}=$ capital market development;

MCAP = market capitalization;

TLNSE = Total Listing of stock and equity;

TVT $=$ Total value of transaction.

\section{RESEARCH METHODS}

The triangulation method of data collection has been used to collect data for the research study. Institutions such as World Bank (2013), Central Bank of Nigeria (CBN), Nigeria Statistical Bulletin (2013), South Africa Statistical Bulletin (2013) were consulted for data generation and improved data quality source for data analysis. The major techniques used for the analysis are Stationarity test of time series data, Johansen Multivariate Co-integration test Vector Autoregressive Model or Unrestricted VAR Model. 


\section{DATA ANALYSIS TECHNIQUE}

The time series and cross sectional data (pooled data) was fitted into regression function and model to determine the relationship between Capital Market Development (CMD) and foreign investment (FI) in Nigeria and South-Africa. Econometrics techniques such as diagnostic test and Granger causality test were used to verify the influence of the model economic indicators of foreign investment attraction in Nigeria and South Africa respectively.

\section{EMPIRICAL RESULTS}

The empirical result of the study are tabulated and explained as follows:

Table 1: Results of diagnostic Test for Capital market Model for Nigeria and South Africa

\begin{tabular}{|l|l|l|l|}
\hline & Models \\
\hline Diagnostic Check & Test & $\begin{array}{l}\text { Nigeria } \\
\text { CMD Model }\end{array}$ & $\begin{array}{l}\text { South Africa } \\
\text { CMD Model }\end{array}$ \\
\hline Autocorrelation & Serial Correlation & 0.72 & 0.56 \\
\hline Heteroskedasticity & Breusch-Pagan L.M & 0.89 & 0.13 \\
\hline \multirow{2}{*}{ Normality } & Jacque-Bera & 79.84 & 97.14 \\
\cline { 2 - 4 } & Prob. & 0.003 & 0.102 \\
\hline Stability & Ramsey Reset Prob. & 0.64 & 0.56 \\
\hline
\end{tabular}

Source: E-views 7.0 Extraction, 2014

From the table 4.1, the diagnostic statistics for Nigeria and South Africa model employs Breusch-Godfrey statistic for detecting serial correlation using LM test. The values of serial autocorrelation tests are 0.72 and 0.56 , which are greater than 0.05 at $5 \%$ level of significance. Hence, there is no autocorrelation problem among the residuals of capital market development model (CMD) indicators. To detect heteroskedasticity error, the probability of F-statistic of the CMD models is 0.89 and 0.13 for the residuals of capital market development (CMD) for Nigeria and South Africa respectively. Therefore, the p-values are higher than $5 \%$ significant level, so the null hypothesis cannot be rejected proving that there is no heteroskedasticity problem. To detect for the normality of the residuals or model errors, the associated probability values of Jargue-Bera statistic are 0.003 and 0.13 . This implies that CMD model for Nigeria has probabilities greater than $5 \%$ significant level, so the null hypothesis is not accepted, which means there is no normality problem, so the error terms are normally distributed. However, the error in the CMD model of South Africa fails normality test.

Model stability test using Ramsey reset F-statistic indicate that p-values for model residuals are 0.64 and 0.56. This shows that CMD models for Nigeria and South Africa are in functional forms. Therefore, to make predictions and estimation, the empirical analysis of the diagnostic check indicates that the CMD model is good for FI predictions in Nigeria and South Africa.

\section{UNIT ROOT ESTIMATION}

Table 2: Results of Unit Root Test for Nigeria

\begin{tabular}{clllllll}
\hline Models & Variable & Order & ADF & $\begin{array}{l}\text { Critical } \\
\text { value }\end{array}$ & $\begin{array}{l}\text { ADF }>\text { Calue } \\
\text { Value }\end{array}$ & Conclusion & At \\
\hline \multirow{2}{*}{ Nigeria } & NFI & I(0) & -3.2164 & -2.9571 & No unit root & Stationary & Level \\
\multirow{2}{*}{ CMD } & NTLNSE & I(1) & -5.5959 & -2.9571 & No unit root & Stationary & $1^{\text {st }}$ diff. \\
& NTVT & I(1) & -6.4938 & -2.9571 & No unit root & Stationary & $1^{\text {st }}$ diff. \\
& SFI & I(1) & -6.2943 & -2.9604 & No unit root & Stationary & $1^{\text {st }}$ diff. \\
& SMCAP & I(1) & -5.8445 & -2.9571 & No unit root & Stationary & $1^{\text {st }}$ diff. \\
$\begin{array}{c}\text { South } \\
\text { Africa } \\
\text { CMD }\end{array}$ & STLNSE & I(0) & -5.6164 & -2.9571 & No unit root & Stationary & $1^{\text {st }}$ diff. \\
& STVT & I(1) & -4.6734 & -2.9571 & No unit root & Stationary & $1^{\text {st }}$ diff. \\
\hline
\end{tabular}


The result from table 4.2 of the unit root test above, there summarizes the unit root test of the variables to examine the stationarity of variables over time. Augmented Dickey Fuller Test (ADF-Test) results confirmed that the variables of Foreign Investment (NFI) and Total listing of stock and equity (TLNSE) are stationary at level $\mathrm{I}(0)$ since the ADF values are far greater than the critical values at $5 \%$ level. In addition, Total Volume of Transaction (TVT) and Market Capitalization (MCAP) are stationary at order 1, $\mathrm{I}(1)$. These results of unit root tests of each variable suggests that there is no presence of unit root as the ADF values are greater than the critical value at $5 \%$. All the variables are stationary.

Table 3: Results of Johansen Co integration Test for Models on FI- Nigeria

\begin{tabular}{|c|c|c|c|c|c|c|}
\hline $\begin{array}{l}\text { Model } \\
\text { on FI }\end{array}$ & $\begin{array}{l}\text { Model } \\
\text { Name }\end{array}$ & $\begin{array}{l}\text { Eigen } \\
\text { Values }\end{array}$ & $\begin{array}{l}\text { Trace } \\
\text { Statistics }\end{array}$ & $\begin{array}{l}0.05 \\
\text { Critical } \\
\text { value }\end{array}$ & Prob** & $\begin{array}{l}\text { Hypothesized } \\
\text { No. of } \\
\text { Cointegrating } \\
\text { Equations (C.E) }\end{array}$ \\
\hline Nigeria & CMD & 0.5498 & 47.7897 & 27.8561 & 0.0007 & None* \\
\hline South Africa & CMD & 0.2016 & 20.4633 & 15.4947 & 0.0468 & At most $2^{*}$ \\
\hline
\end{tabular}

Trace test indicates cointegrating eqn(s) at the 0.05 level $*$ denotes rejection of the hypothesis at the 0.05 level **MacKinnon-Haug-Michelis (1999) p-values

Source: E-Views statistical package version 7

Empirical results from table 4.3 indicates that Johansen Co integration test for all the CMD model for foreign investment in Nigeria reveals that both the maximum eigenvalue and trace tests statistics (L.R) have values greater than the critical values at 5 percent levels of significance $(* *)$. Therefore, the null hypotheses of no co integrating vectors ( $r=0 ; r \leq 1)$ against the specific alternatives are clearly rejected. Capita market development (CMD) is co integrated at none*. This implies at least 1 co integrating equation for Nigeria. However, Capita market development (CMD) is co integrated at most 2* in South Africa. Therefore, there is at least 3 co integrating equation. There is clear evidence that long run equilibrium relationships existed among CMD economic indicators and foreign investment in Nigeria and South Africa.

Table 4: Results of Granger Causality Test of CMD on FI for Nigeria and South Africa

\begin{tabular}{|l|l|l|l|l|l|l|}
\hline CMD model on FI & \multicolumn{1}{c|}{ Nigeria } & & \multicolumn{2}{c|}{ South Africa } \\
\hline Null Hypothesis & Obs & F-stat & Prob. & Obs & F-stat & Prob. \\
\hline NMCAP does not Granger Cause FI & & 3.8853 & 0.0329 & & 2.7595 & 0.0812 \\
FI does not Granger Cause MCAP & 32 & 0.3068 & 0.7353 & 32 & 2.7163 & 0.0842 \\
\hline TLNSE does not Granger Cause FI & & 1.1962 & 0.3179 & & 1.7163 & 0.1988 \\
FI does not Granger Cause TLNSE & 32 & 0.3479 & 0.7093 & 32 & 2.2822 & 0.1214 \\
\hline TVT does not Granger Cause FI & & 10.5160 & 0.0004 & & 0.4152 & 0.0255 \\
FI does not Granger Cause TVT & 32 & 0.0149 & 0.9852 & 32 & 2.0057 & 0.1541 \\
\hline
\end{tabular}

For Nigeria, granger causality results in table 4.4 show that there is causal relationship from the market capitalisation (NMCAP) and total value of transaction (NTVT) to Foreign Investment (NFI) but NFI does not granger cause NMCAP. However, total listing stock and equity (STLNSE) does not granger cause foreign investment (NFI) and vice versa. There is some evidence of causality from NMCAP and STVT on foreign investment (NFI) as the associated probability values is less than 0.05 at $5 \%$ critical level. There is short run causal relationship of among some of the indicators-NMCAP and NTVT on foreign investment (NFI) but not vice versa. In South Africa, the granger causality results of market capitalisation model reveals that only total value of transaction granger cause foreign investment (SFI) but SFI does not granger cause STVT. A short run equilibrium relationship exists between SMCAP and SFI. While in the no run relationship exist among total listing of stock and equity, market capitalisation (MCAP) and foreign investment (SFI) in South Africa.

\section{CONCLUSION AND RECOMMENDATIONS}

The study has been able to establish that the main foreign investment indicators with respect to the two countries model development is the value added tax for the tax forms economic indicators. Total value of transaction and market capitalisation are capital market model economic indicators influencing foreign 
investment in Nigeria and South Africa in the short run. In general, granger causality finding reveals that: MCAP and TVT influence FI in Nigeria on the short run while INT influences FI in South Africa in the short run. None of the tax form indicators influence FI in Nigeria and South Africa since there is no granger causality between the indicators and FI in the two countries.

From the empirical findings of the study, the following recommendations are made: there should be reforms in the capital market to enhance the level of robustness of its indicators to attract and influence foreign investment in Nigeria and South Africa. Substantial approach and working policy making and implementation in the stock exchange market to improve quality portfolio that will attract foreign investors in the global financial market.

\section{REFERENCES}

- Ali A. (2012). Banking Sector Development and Economic Growth in Lebanon. International Research Journal of Finance and Economics. ISSN 1450-2887 Issue 100. http://www.internationalresearchjournaloffinanceandeconomics.com

- Angela S, Ini S.U, Audu S., Ngozi V.A and Baba N.Y (2014). Developing Banking System Stability Index for Nigeria. CBN Journal of Applied Statistics Vol. 5 No. 1.

- Central Bank of Nigeria Statistical Bulletin 2013

- Demirgue, Kunt A.; Levin, R. (1996). Stock Market Development and Financial Intermediaries: Stylized Facts. The World Bank Economic Review, 10(2): 241-265.

- Kolapo F T \&Adaramola A O 2012, 'The Impact of the Nigerian Capital Market on Economic Growth (1990-2010)', International Journal of Developing Societies Vol. 1, No. 1, 2012, 11 19.

- Levine, R.; Zervos, S. (1996). Stock Market Development and Long-term Growth. The World Bank Economic Review. 10 (3):323-339.

- Maysami R.C (2004), "Relationship between Macroeconomic Variables and Stock Market Indices: Co-integration Evidence from Stock Exchange of Singapore's All Sector Indices.

- Mohammed S.D, Hussain .A., Jalil M.A, and Ali A. (2009), "Impact of Macroeconomic Variables on Stock Prices: Empirical Evidence in case of KSE (Karachi Stock Exchange)". European Journal of Scientific Research ISSN 1450-216X Vol. 38 No 1 (2009), PP. 96-103.

- Onuorah .A.C and Akujuobi .L.E. (2013), "Impact of Macroeconomic Indicators on the Performance of Foreign Portfolio Investment in Nigeria. European Journal of Business and Management. ISSN 2222-1905 (paper) ISSN 2222-2839 online Vol. 5 No 2.

- Rugman, A.M. and Verbeke, A (1981), "Internalization Theory and its Impact on the Field of International Business", Vol. 14 pp.155-174.

- Salako H.A \& Adebusuyi B.S (2000). Determinants of Foreign Direct Investment (FDI) in Nigeria: An Empirical Investigation. CBN Economic \& Financial Review, Vol.39 No.1.

- $\quad$ South-Africa Statistical Bulletin 2013.

- World Bank, World Bank Human development Classification Indicator Report, 2013.

- World Bank, World Development Indicators, 2013.

- World Bank, Global Economic Prospects, 2012.

- World Bank, "World Development Indicators, 2002.

- World Bank, Economic Development Indicators, 2013. 